\title{
STRATEGI PEMASARAN DALAM UPAYA PENINGKATAN OMSET PENJUALAN UMKM DESA SUMBER KEMBAR, KECAMATAN PACET, KABUPATEN MOJOKERTO
}

\author{
Nikmatus Sholicha, Renny Oktafia \\ Fakultas Agama Islam Sidoarjo, Universitas Muhammadiyah Sidoarjo \\ Email Korespondensi: nikmatussholicha11@gmail.com
}

\begin{abstract}
Micro, Small and Medium Enterprises (MSME) in Indonesia have an increasing number from year to year. Starting from 2012 to 2017 the development of MSME reached 13.98 percent. percentage in 2017, MSME have reached the number of 62,922,617 units in various regions in Indonesia, of course the number is much larger than the large businesses that only amounted to 5,460 units. Largest amount was donated by micro businesses as much as 62 million (98.7 percent), with small and medium enterprises amounting to 815 thousand units or only 1.3 percent. Sumber Kembar village is also a contributor to the unit. but still have difficulty in implementing the right marketing strategy. Research aims to know the implementation of marketing strategies in an effort to increase the sales turnover of MSME Sumber Kembar village and as an education on the impact caused. type of research method used qualitatively with case study approach. MSME in the village use offline steps in a product marketing that makes their turnover small and the business difficult to develop. if the MSME in Sumber Kembar village do not follow the development of technology, then they will be difficult to compete with other competitors who have advanced.
\end{abstract}

Keywords : MSME, marketing strategy

\section{PENDAHULUAN}

Usaha Mikro Kecil dan Menengah (UMKM) menjadi sebuah pondasi kegiatan ekonomi yang mampu memulihkan kondisi perekonomian. Dalam hal ini, peran UMKM sangat besar kontribusinya terhadap perekonomian Indonesia. UMKM memiliki jaringan luas hingga keberbagai plosok negeri yang mampu merangkul serta menghidupkan potensi masyarakat secara meluas, sehingga masyakat akan mendapatkan kehidupan yang berkemajuan menjadi lebih baik.

UMKM di Indonesia sendiri memiliki jumlah yang terus meningkat dari tahun ke tahun. Mulai dari tahun 2012 hingga tahun 2017 perkembangan UMKM mencapai 13,98 persen. Pada diagram berikut bisa kita lihat presentase pada tahun 2017, UMKM telah mencapai jumlah sebanyak 62.922.617 unit di berbagai wilayah di Indonesia, tentu saja jumlah tersebut jauh lebih besar dibandingkan usaha besar yang hanya berjumlah 5.460 unit. Dari banyaknya jumlah UMKM tersebut, jumlah terbesar didoninasi oleh usaha mikro sebanyak 62 juta (98.7 persen), dengan usaha kecil dan menengah sebesar 815 ribu unit atau hanya 1.3 persen (Kementerian Perencanaan Pembangunan Nasional, 2018). Berdasarkan analisis data diatas dapat dilihat pada diagram berikut:

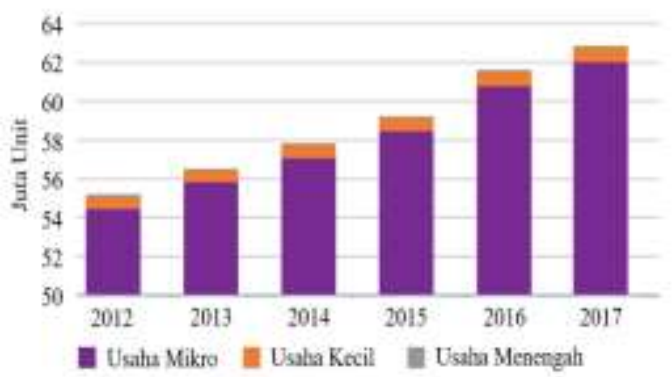

Sumber : (Kementerian Perencanaan Pembangunan Nasional, 2018)

Gambar 1. Perkembangan UMKM di Indonesia

UMKM merupakan sebuah pondasi perekonomian yang diharapkan mampu memulihkan 
krisis ekonomi. Potensi UMKM yang begitu besar dalam menyerap tenaga kerja dan tentu saja perlu terus menerus dilakukan peningkatan agar maksimal (Oktafia, 2017). UMKM diharapkan menjadi pelaku utama yang mempunyai produktivitas dan daya saing dalam skala perekonomian nasional dimana terdapat tiga komponen yang selalu menyertai yaitu, perusahaan, konsumen dan kompetitor (Setiawati, 2017).

Dalam peranannya UMKM dianggap memiliki peran yang penting bagi kemajuan perekonomian terutama di Indonesia, mampu mandiri dalam suatu kegiatan ekonomi, sebagai buktinya UMKM mampu berusaha tanpa adanya dukungan dari pihak lain dimana modal dan teknologi yang dipakai adalah milik sendiri yang dianggap penting bagi para pelaku ekonomi agar mampu bersaing dengan pengusaha yang lain dalam perebutan pasar (Arliman S, 2017).

Menurut Iman dan Adi 2009 di dalam (Wibowo et al., 2015) Usaha Mikro Kecil Menengah (UMKM) merupakan sebuah kegiatan yang mampu memperluas lapangan pekerjaan, mampu memberikan pelayanan ekonomi secara meluas kepada masyarakat, mampu menjadikan proses pemerataan dan peningkatan pada pendapatan masyarakat serta mampu mendorong pertumbuhan ekonomi dalam mewujudkan stabilitas nasional.

Pada era globalisasi seperti saat ini khusunya dengan adanya integrasi ekonomi pada Asia Tenggara, yakni model penyatuan ekonomi yang menjadikan Asia Tenggara sebagai suatu komunitas ekonomi yang berbasis produksi tunggal menjadikan UMKM harus mampu untuk mempertahankan eksistensinya ditengah pertempuran ekonomi global seperti saat ini. Tentu saja dalam hal ini UMKM dituntut untuk mampu bersaing dan menciptakan suatu produk yang tidak hanya dapat diterima oleh konsumen dalam negeri tetapi juga oleh Asia Tenggara (Sarfiah et al., 2019). UMKM pada umumnya berguna sebagai penggerak perekonomian rakyat yang memiliki peranan penting bagi pertumbuhan ekonomi serta industri sebuah desa bahkan suatu negara serta dituntut untuk selalu melakukan perubahan guna memperkuat daya saing (Esti Prastika \& Edi Purnomo, 2019).

Dalam UMKM (Usaha Mikro Kecil dan Menengah) juga memerlukan adanya sebuah strategi pemasaran dalam memperkenalkan kegiatan usahanya. Karena dengan adanya strategi pemasaran yang efektif maka masyarakat akan lebih mudah mengenal sehingga akan menciptakan sebuah sumber lapangan pekerjaan yang luas. Gambaran secara umum tentang sistem pemasaran bahwa seseorang (individu) atau sebuah organisasi (kelompok orang) mereka menciptakan sebuah produk atau menawarkan sebuah produk yang mereka miliki kepada orang lain dengan tujuan agar orang tersebut mau membeli produk yang mereka buat atau tawarkan tersebut sehingga terciptalah yang disebut dengan pemasaran. Namun tidak mudah begitu saja dalam melakukan pemasaran terutama pada era globalisasi seperti ini, dimana teknologi mulai dikerahkan, mereka yang tidak menggunakan teknologi dalam bertransaksi tentu saja akan tertinggal (Sembiring \& Siregar, 2020).

Desa Sumber Kembar merupakan sebuah desa yang terletak pada wilayah pedalaman di Kecamatan Pacet, Kabupaten Mojokerto, Propinsi Jawa Timur. Uniknya meskipun dalam kawasan matapencaharian masyarakatnya sebagai petani, namun tidak seluruhnya mendedikasikan hidup mereka sebagai seorang petani tetapi ada juga yang memilih untuk berwirausaha dengan mendirikan rumah industri (home industry). Tidak mudah mengenalkan produk home industry dari desa Sumberkembar meskipun berasal dari kawasan wisata Pacet karena kurangnya eksistensi dari desa ini.

Kelemahan pada desa Sumber Kembar yaitu warga desanya yang belum bisa atau belum memahami dalam mem-branding-kan produk mereka. Banyak warga yang belum memahami terkait strategi pemasaran yang dapat mereka lakukan untuk memasarkan produk mereka. Desa Sumber Kembar sebuah lingkup desa yang terletak pada area pedalaman dan memiliki koneksi jaringan internet yang buruk dan terbatas sehingga tidak semua wilayah dapat menjangkau internet pada wilayahnya yang mengakibatkan tidak mudah untuk memasarkan produk dari desanya dan akhirnya banyak warga yang memilih untuk mengelolah bahan baku menjadi bahan jadi yang kemudian mereka konsumsi sendiri.

Produk merupakan sesuatu yang diciptakan dan ditawarkan ke pasar untuk dikonsumsi, diperlihatkan, dipakai bahkan dimiliki yang bertujuan untuk memenuhi kebutuhan atau hanya sekedar memuaskan keinginan. Dari pengertian tersebut dapat diambil kesimpulan bahwa hasil produksi adalah benda yang nyata dan dapat dilihat serta dirasakan, karena produk merupakan sejenis benda nyata yang memiliki jenis beraneka ragam (Firmansyah, 2019).

Menurut kepala sekolah bapak Suharno, Spd.i di SD Sumber Kembar mengatakan bahwa warga desa Sumber Kembar kreatif - kreatif orangnya hanya saja mereka tidak mengerti cara memasarkan produk sehingga hanya pada wilayah sekitar desa saja mereka menjajakan dagangan mereka. Untuk menciptakan daya pola pikir kreatif tidaklah mudah dan bukan merupakan hal instan namun membutuhkan tenaga dan waktu serta terus berjuang tanpa kenal menyerah. Kecerdasan belum menjamin seseorang untuk menjadi pribadi dengan pemikiran yang kreatif, sukses dan sejahtera bila orang tersebut hanya puas dengan kecerdasan yang dimilikinya tanpa adanya pemikiran untuk 
meningkatkan dan mengembangkan potensi dari bakat yang dimilikinya tersebut menurut Dariyo (2003) dalam (Hendrawan et al., 2019).

Pentingnya UMKM bagi kemajuan suatu wilayah maka dari itu perangkat desa Sumber Kembar bersepakat untuk memberikan arahan kepada warga agar optimis dalam menjalankan suatu usaha dan tidak mudah menyerah apabila mengalami kegagalan. Perlu diadakan sebuah penerapan strategi pemasaran.

Omzet atau sering dikenal dengan kata omset yang berarti jumlah, sedangkan penjualan merupakan kegiatan menjual produk atau benda yang bertujuan untuk mencari keuntungan atas laba atau pendapatan (Jatmika et al., 2017). Menurut Swastha (1993) dalam (Jatmika et al., 2017), omset penjualan merupakan suatu kegiatan penjualan berupa produk barang maupun jasa yang berakumulasi serta dapat dihitung secara menyeluruh dalam kurun waktu tertentu secara kontinu dalam sebuah proses akuntansi.

Secara umum strategi sering kita artikan sebagai suatu cara untuk mencapai tujuan. Menurut Porter (2012) dalam (Yunus, 2016) Strategi adalah sekumpulan aktivitas yang memiliki tindakan berbeda - beda sehingga membentuk nilai yang unik. Sedangkan menurut Arthur A. J., (2007) dalam (Yunus, 2016) strategi merupakan aktivitas - aktivitas yang memiliki daya saing serta pendekatan pendekatan bisnis yang bertujuan mencapai kinerja yang diinginkan atau sesuai dengan target.

Strategi merupakan suatu tindakan yang terdiri dari perencanaan, pengorganisasian, pengarahan, dan pengendalian atas suatu keputusan serta tindakan terkait strategi dari perusahaan (Yunus, 2016).

Menurut Kotler dan Keller 2009:9 dalam (Sembiring \& Siregar, 2020) pemasaran adalah sebuah proses sosial dan manajerial yang memuat individual maupun kelompok untuk mendapatkan apa yang mereka inginkan dan butuhkan yang dilakukan dengan cara menukarkan, menawarkan maupun menciptakan produk dan jasa yang memiliki nilai dengan pihak lainnya.

Strategi pemasaran merupakan sebuah cara untuk menunjukkan keunggulan suatu produk bertujuan untuk memenangkan persaingan pemasaran secara berkesinambungan baik untuk perusahaan produksi barang maupun jasa (Wibowo et al., 2015).

Strategi pemasaran adalah rangkaian pengambilan keputusan yang meliputi biaya pemasaran, bauran pemasaran, alokasi dari pemasaran tersebut dalam hubungan keterkaitan terhadap keadaan lingkungan yang diharapkan dan keadaan persaingan (Priangani, 2013).

Pada dasarnya strategi pemasaran adalah suatu rencana secara menyeluruh yang terpadu dan menyatu yang terdapat pada bidang pemasaran barang dan jasa.
Dalam kata lain, strategi pemasaran adalah serangkaian langkah yang memiliki tujuan serta adanya sasaran kebijakan yang memberikan arahan pada para pelaku usaha pemasaran baik barang maupun jasa (Sembiring \& Siregar, 2020).

Strategi pemasaran produk merupakan suatu cara yang diciptakan dengan sebuah proses sosial dan manajerial yang dilakukan individu maupun kelompok untuk mencapai sebuah target yang mereka inginkan terhadap produk yang telah mereka buat agar tercapainya sebuah strategi pemasaran produk yang optimal. Dalam strategi pemasaran yang baik akan memberikan dampak baik terhadap omset penjualan yang diharapkan.

\section{METODE PENELITIAN}

Peneliti menggunakan jenis metode penelitian kualitatif dengan pendekatan studi kasus. Jenis metode kualitatif cocok diterapkan pada peneliti yang meneliti mengenai strategi pemasaran dalam upaya peningkatan omset penjualan desa Sumber Kembar, Kecamatan Pacet, Kabupaten Mojokerto dalam memahami suatu permasalahan yang keadaannya masih meraba - raba atau belum pasti dan cenderung berubah - ubah.

Peneliti menggunakan jenis data primer dan data sekunder yang diperoleh dari hasil wawancara secara langsung dengan pengadaan wawancara kepada responden, melakukan observasi, bahkan peneliti turut andil dalam proses penelitian sehingga dapat mengetahui lebih mendalam mengenai subtansi yang diteliti dan dari web site desa Sumber Kembar (Rukajat, 2018).

Lokasi penelitian dilakukan di Desa Sumberkembar, kecamatan Pacet, Kabupaten Mojokerto, Jawa Timur 61374. Berikut proses pengambilan data oleh peneliti:

\subsection{Observasi}

Dalam melakukan pengambilan data, peneliti melakukan pengamatan terhadap kegiatan usaha yang mereka lakukan serta bagaimana mereka akan memasarkan produk - produk yang mereka miliki dari mulai pembuatan, pengemasan, hingga pengiriman ke beberapa daerah untuk dipasarkan.

\subsection{Wawancara}

Peneliti menggunakan pengambilan data dengan melakukan wawancara kepada para pengelola usaha (UMKM) atau kepada pemilik dari rumah industri tersebut agar memperoleh informasi yang akurat dan lengkap.

\subsection{Dokumentasi}

Peneliti melakukan dokumentasi berupa gambar terhadap beberapa kegiatan usaha yang mereka jalankan 
serta tahapan yang mereka lakukan terhadap produk yang dibuat.

\section{HASIL DAN PEMBAHASAN}

\subsection{Keadaan Ekonomi dan Sosial Warga Desa Sumber Kembar}

Termasuk memiliki sumber daya manusia yang cukup, dalam artian tidak terlalu padat penduduk juga tidak terlalu sedikit. Berdasarkan hasil pemetaan sosial PPL 2015 diperoleh data sebanyak 3.180 jiwa yang bermukim di Desa Sumber Kembar dengan rincian 1.609 penduduk laki-laki dan 1.571 penduduk wanita.

Berdasarkan dari penelitian yang dilakukan oleh peneliti memperoleh data kondisi ekonomi desa Sumber Kembar sebagai berikut:

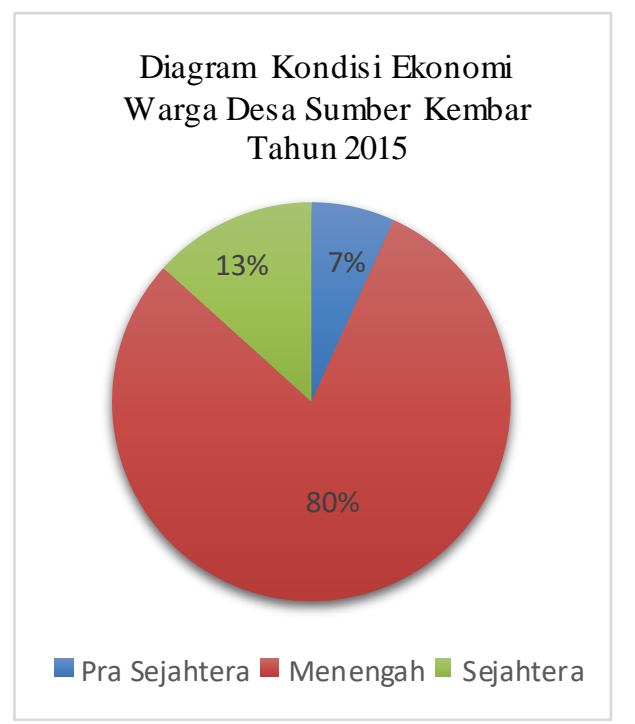

Sumber: Pemdes Sumber Kembar (2018)

Gambar 2. Kondisi Ekonomi Warga Desa Sumber Kembar

Dari data tersebut dapat disimpulkan bahwa penduduk prasejahtera sebesar 7\% dari jumlah penduduk 946 KK, maka dari itu desa Sumber Kembar termasuk memiliki penduduk yang memadai. Termasuk dalam kawasan desa yang masyarakatnya berpendidikan, Desa Sumberkembar merupakan sebuah desa yang terletak pada kawasan Pacet yang mana sebagian besar penduduknya bermata pencaharian sebagai petani. Hal ini dikarenakan tidak semua warganya menempuh pendidikan hingga sarjana. Meskipun tidak semua warga desa Sumber Kembar yang lulusan sarjana tetapi sebagian warganya memiliki pemikiran yang maju. Tofa warga desa Sumber Kembar yang hanya lulusan SMA mendirikan sebuah pabrik pengolahan kripik ketela yang berlokasi di Desa Sumber Kembar, Kecamatan Pacet, Kabupaten Mojokerto. Ia juga memiliki bebrapa pegawai di pabriknya.
Terdapat pula pengusaha kripik usus yang hanya lulusan SMP yang juga mendirikan sebuah pabrik di Desa Sumber Kembar dengan harapan para pengusaha ini bisa meminimalisir pengangguran yang ada di Desa Sumber Kembar tersebut.

\subsection{Penerapan Strategi Pemasaran Dalam Upaya Peningkatan Omset Penjualan UMKM Desa Sumber Kembar, Kecamatan Pacet, Kabupaten Mojokerto}

Para pengusaha menerapkan strategi pemasaran secara manual yaitu dengan memperkenalkan atau mempromosikan produk mereka ke distributror bahkan ke retail - retail, ada juga yang menjualkan dagangannya langsung ke pasar. Berbagai cara yang ditempuh oleh pembuat atau pemilik UMKM ini bertujuan agar dagangan produksi mereka dikenal oleh masyarakat luas dan dapat menambah lapangan pekerjaan bagi warga sekitar desa Sumber Kembar. Selain itu agar dapat meningkatkan omset penjualan.

\subsubsection{Pemasaran produk dilakukan secara manual (offline)}

Penjualan yang dilakukan oleh pemilik pelaku usaha ini tidak dilakukan secara online dikarenakan produk yang mereka jual tidak akan bertahan lama alias hanya beberapa bulan saja bahkan ada yang hanya dengan itungan hari produk tersebut busuk. Para pelaku usaha di desa Sumber Kembar mengakui bahwa penjualan mereka hanya dilakukan secara offline dan tidak di distribusikan ke tempat - tempat yang jauh dikarenakan ketahanan produk yang tanpa penggunaan bahan pengawet.

Beberapa pelaku usaha di Desa Sumber Kembar yang sempat ditemui oleh peneliti seperti pengusaha kripik ketela, pengusaha susu sari kedelai, pengusaha kripik usus, pengusaha nugget ampas kedelai berpendapat bahwa pemasaran yang dilakukan secara offline (manual) dianggap lebih mudah karena mereka dapat berinteraksi dengan pembeli dan dapat memperoleh informasi maupun kritikan dari pembeli tersebut mengenai produk yang mereka jual.

\subsubsection{Belum mampu menggunakan marketplace pada aplikasi sebagai upaya peningkatan omset}

Penjualan yang dilakukan secara online dianggap terlalu rumit karena harus memiliki akun toko online seperti di Instagram, shopee, tokopedia maupun marketplace di facebook. Memasang produk secara online haruslah dengan gambar produk tersebut yang di foto dengan sisi yang bagus agar mendapatkan hasil gambar yang maksimal dan menambah kepercayaan masyarakat terhadap produk tersebut. 
Pemasaran secara online memerlukan seorang admin yang mahir dalam mengelola marketplace dan juga tidak gaptek selain itu sedikit banyak memahami tentang editing. Tentunya sebagai seorang admin harus cekatan dan sabar dalam melayani pembeli di Toko online. Semua hal tersebut dilakukan dengan maksud agar menarik minat pembeli.

Para pelaku usaha ini enggan melakukan hal tersebut karena seolah mereka harus bekerja ekstra sedangkan mereka juga memiliki keluarga dan kegiatan rutin lain yang tidak bisa diabaikan. Alasan lain karena anak muda di Desa Sumber Kembar yang paham teknologi enggan bekerja sebagai admin meskipun para pelaku usaha ini membuka open recruitment pekerjaan tersebut dan menganggap bekerja di pabrik diluar kota lebih menguntungkan dari pada menjadi seorang admin dengan penghasilan kecil.

\subsubsection{Pemasaran produk susu sari kedelai}

Awal mula pendiriannya, pemasaran yang dilakukan yaitu dengan cara menitiptan dagangan dagangan di toko retail dan pedagang jalanan keliling. Namun sering tidak mencapai omset yang diharapkan dan pemasaran dalam bentuk tersebut kadang sering tidak laku bahkan kurang peminat yang mana hanya warga sekitar tempat pembuatan susu sari kedelai saja yang mengetahui. Dari pengalaman yang telah pemilik pengusaha tersebut lalui maka tidak lagi menitipkan dagangannya ke toko retail dan pedagang jalanan, akan tetapi menjajakan dagangannya ke para pelaku usaha di Pasar - pasar. Seiring berjalannya waktu selama lebih dari 3 tahun ini pemilik telah mendapatkan pelanggan yang selalu memesan susu sari kedelai.

Sistem penjualan yang dilakukan melalui via chat pribadi dari pelanggan yang memesan dan memproduksi sesuai pesanan pelanggannya dengan jumlah yang pas (tidak dilebihkan) kemudian keesokan harinya hanya tinggal memberikan pesanan - pesanan tersebut ke pelanggan sehingga tidak ada susu sari kedelai yang terbuang percuma (busuk). Pemilik usaha menjelaskan bahwa lebih baik memproduksi dengan jumlah pas sesuai pesanan dan mendapat kekecewaan dari pelanggan yang tidak memesan sebelumnya (stok kehabisan) dari pada melebihkan jumlah produksi yang belum pasti dan berakhir kerugian.

\subsubsection{Pemasaran produk kripik ketela}

Pemilik pengusaha pabrikan kripik ketela merupakan seorang lulusan SMA yang mana ingin meneruskan usaha kedua orang tuanya yaitu jualan kripik ketela. Namun orang tuanya telah vacum dari bisnis tersebut selama beberapa tahun dikarenakan penjualannnya tidak mampu menembus omset yang diharapkan. Selain itu keperluan ekonomi yang semakin mencekik membuat usaha orang tuanya gulung tikar.

Setelah kelulusannya dari SMA, mas Tofa (pemilik usaha) mendirikan pabrik tersebut dengan modal dari tabungan yang dimiliki pada tahun 2016 dengan harapan mampu menghidupkan kembali usaha orang tuanya dan dapat membuka lapangan pekerjaan bagi warga sekitar.

Bermula dari produksi sendiri yang kemudian dipasarkan sendiri dengan menawarkan dagangannya ke toko - toko retail baik di Mojokerto maupun area luar kota Mojokerto dan pasar pusat oleh - oleh khas pacet. Dari usaha - usaha yang dilakukan tersebut omset penjualan mereka lancar dan stabil. Maka dari itu pemilik mulai berani untuk merekrut karyawan hingga pada akhirnya di tahun 2018 hingga awal tahun 2020 penjualan kripik ketela mencapai masa jayanya. Dimana omset penjualan mereka naik meskipun dilakukan secara offline.

Masa kejayaan ini tidak berangsur lama karena di tahun pertengahan 2020 hingga saat ini omset penjualan kripik ketela menurun karena pandemi covid-19 dan tidak dapat di distribusikan ke tempat pelanggan dan juga adanya PSBB pada tiap - tiap wilayah membuat pemilik menurunkan jumlah produksi dan merugi karena ada ketela yang membusuk.

Pembuatan kripik ketela tanpa menggunakan bahan pengawet sehingga kripik yang sudah jadi dan dibungkus dalam kemasan hanya mampu bertahan kisaran 3 bulan. Supaya produk fresh lebih lama ditangan reseller, pengelola akan memproduksi sesuai pesanan pelanggan (reseller) dari hari sebelumnya, kemudian di kemas dan di kirimkan beberapa hari setelah pemesanan.

\subsubsection{Pemasaran produk kripik usus}

Kripik usus dipasarkan dengan cara meletakkan dagangan ke toko - toko retail, warung dan rumah rumah makan yang mana hasil (uang) akan didapatkan pemilik apabila kripik usus sudah laku terjual. Namun ada juga kripik yang sudah dikemas dalam jumlah tertentu dan diberi label dipasarkan ke luar kota.

Kripik usus hanya bertahan dalam jangka waktu 3 bulan, lebih dari itu produk tersebut akan melempem. Kripik usus diproduksi dalam sebuah pabrik yang memiliki karyawan didalamnya. Pemilik usaha kripik usus ini adalah seorang ibu rumah tangga yang memiliki banyak aktifitas diluar. Sehingga sama seperti pelaku UMKM dominan di Desa Sumber Kembar belum bisa melakukan penerapan pemasaran secara online.

\subsubsection{Pemasaran produk nugget ampas kedelai}

Nugget ampas kedelai adalah produk olahan dari ampas kedelai yang dicampur dengan sedikit 
daging ayam di produksi oleh rumahan yang mana pengelola utamanya adalah kepala dusun Sumber Kembar. Bermula dari pengusaha susu sari kedelai yang sering membuang ampas kedelai bahkan biasa dipakai pakan ternak di Desa Sumber kembar. Namun melihat peluang ini, ada mahasiswa KKN di desa tersebut yang mencetuskan ide untuk membuat nugget ampas kedelai karena dari pada ampas tersebut dibuang dan hanya jadi pakan ternak.

Nugget tersebut dipasarkan ke sekolah - sekolah di Desa Sumber Kembar, karena sebagian besar peminatnya adalah anak - anak. Harga yang terjangkau karena diproduksi oleh rumahan membuat nugget ampas kedelai laku keras namun hanya di daerah Sumber Kembar saja. Harapan dari pengelola agar produk tersebut dikenal diberbagai wilayah bahkan luar kota mojokerto. Akan tetapi sangat disayangkan karena produk tersebut belum mampu menembus pasar internasional karena ketahanan produk dan kemasan yang digunakan mempengaruhi cita rasa produk.

Dalam pengemasannya nugget ampas kedelai menggunakan plastik tebal yang dipanaskan dengan alat sehingga kedap udara, meski demikian tidak mampu bertahan lama karena tidak adanya pengawet dan kurang canggihnya alat yang digunakan untuk menutup pembungkus sehingga masih ada udara yang tertinggal dalam kemasan. Hal tersebut membuat produk hanya mampu bertahan selama maksimal 10 hari dalam freezer. Maka dari itu produk ini belum mampu untuk mencapai omset yang diharapkan.

\subsubsection{Tidak menggunakan bahan pengawet pada produk \\ Penggunaan bahan pengawet pada produk} dinilai berbahaya oleh pelaku pengusaha di Desa Sumber Kembar karena kandungan bahan kimia yang terdapat pada bahan pengawet tersebut sehingga dikhawatirkan akan berdampak pada kesehatan konsumen. Warga disana sering mengolah bahan makanan mentah menjadi bahan jadi yang kemudian dikonsumsi sendiri dengan alasan lebih sehat. Tentu saja ini juga yang mendasari mengapa para pengusaha enggan memasukkan pengawet pada produknya namun tetap ingin produknya mencapai omset yang besar dan dapat didistribusikan keberbagai wilayah.

Salah satu alasan tidak adanya pengawet pada produk mereka karena para pelaku usaha belum mengetahui takaran pengawet yang pas yang bisa mereka pergunakan pada produk mereka, jadi mereka masih ragu dalam penggunaan bahan pengawet.

Saat ini para pelaku usaha di Desa Sumber Kembar sebagian akan menerapkan pemberian pengawet pada produknya dan masih mengikuti pelatihan - pelatihan pemberian bahan pengawet yang aman pada produk. Pelatihan tersebut diselenggarakan diluar kota dan tidak semua orang bisa mengikuti pelatihan tersebut. Selain karena waktu juga karena pelatihan tersebut berdasarkan undangan yang dibatasi.

\subsubsection{Ketahanan produk tanpa pengawet makanan}

Peneliti melakukan wawancara pada pengusaha susu sari kedelai yang mana produk mereka hanya bertahan 2 hari bila dimasukkan dalam freezer dan 1 hari saja apabila dibiarkan di udara terbuka, karena lebih dari hari itu tentunya rasa susu sari kedelai akan berubah dan tidak sesegar hari pertama saat dijual (busuk).

Pengolahan (pembuatan) susu sari kedelai sendiri dimulai saat tengah malam atau pagi - pagi buta yang mana produk yang telah jadi dibuat akan langsung dipasarkan oleh pembuat sekaligus pemilik pengusaha. Pengusaha sari kedelai mengakui bahwa dagangan mereka sering habis karena sudah di borong oleh pelanggan, sedangkan pelanggan yang datangnya terlalu siang tidak mendapat bagian yang berujung kecewa. Pengusaha enggan memproduksi lebih karena produknya pernah tidak laku bahkan busuk hingga mengalami kerugian tapi disaat mereka mengurangi jumlah produksi, permintaan justru meningkat.

Produk yang lebih cepat busuk lagi yaitu nugget ampas kedelai yang tanpa pengawet hanya bertahan tidak lebih dari 10 hari dalam freezer. Lain halnya dengan kripik usus dan kripik ketela yang mampu bertahan hingga 3 bulan meskipun tanpa bahan pengawet.

Permintaan pasar yang sering naik turun tidak dapat terbaca oleh para pelaku pengusaha sehingga mereka menurunkan pembuatan produknya. Maka dari itu masyarakat perlu pelatihan penggunaan bahan pengawet. Pelatihan penambahan bahan pengawet pada makanan dirasa sangat perlu bagi warga desa Sumber Kembar agar produk yang pereka buat tidak cepat melempem, basi bahkan busuk. Penggunaan bahan pengawet yang sesuai takaran rekomendasi dari bidang pangan (ahli gizi) tentu tidak akan mempengaruhi rasa produk, justru akan mempertahankan karakteristik produk tersebut agar sampai ke tangan konsumen dengan aman tanpa ada yang melempem maupun busuk.

\subsubsection{Pengawet makanan dapat mengubah cita rasa produk makanan}

Pengusaha kripik ketela, kripik usus dan nugget ampas kedelai juga belum bisa memberikan bahan pengawet kedalam produk makanannya, karena masih ingin mempertahankan rasa khas dari produk tersebut tanpa pengawet. Berdasarkan wawancara yang sempat dilakukan peleniti ke beberapa pengusaha terkait tidak adanya pemberian bahan pengawet pada makanan dikarenakan khawatir akan merubah cita rasa produk 
yang mereka buat, karena masih ada sebagaian warga disana beranggapan bahwa pemberian bahan pengawet menandakan bahwa produk tersebut memiliki kualitas yang buruk.

\subsubsection{Produk diproduksi dalam jumlah terbatas}

Pembatasan produksi bukan berarti tidak ingin meningkatkan omset penjualan. Akan tetapi pembatasan dilakukan supaya tidak terlalu banyak bahan yang dibuang apabila produk tidak laku dipasaran selama kurun waktu tertentu. Seperti yang kita ketahui bahwa produk - produk di Desa Sumber Kembar masih asli belum tercampur bahan pengawet.

Pengusaha kripik ketela, kripik usus dan susu sari kedelai produknya diproduksi sesuai permintaan, karena tidak ingin terjadi kerugian yang besar. Seperti yang pernah dialami oleh pengusaha susu sari kedelai yang memproduksi dagangannya dalam jumlah banyak sehingga ketika produk mereka tidak laku akhirnya mengalami kerugian apalagi produk susu sari kedelai hanya mampu bertahan 2 hari jika dimasukkan dalam3.3 freezer. Sedangkan pemasaran nugget ampas kedelai memang diproduksi dalam jumlah terbatas karena pelaku usahanya masih memproduksi manual di Rumah - rumah bukan seperti pengusaha kripik ketela, kripik usus yang sudah memiliki pabrik.

Para pelaku usaha di Desa Sumber Kembar juga masih enggan menggunakan aplikasi marketplace seperti Shopee, Tokopedia, Facebook bahkan Instagram yang tentu saja bisa mereka manfaatkan terutama di era milenial dan masa pandemi covid-19 sebagai penunjang omset penjualan dimana masyarakat akan lebih mengenal produk mereka dikarenakan produk mereka belum tentu ready dalam jumlah yang diinginkan. Meskipun pada beberapa aplikasi tersebut ada fitur Pre-Order namun para pelaku usaha enggan menggunakan karena terbatasnya waktu.

\subsubsection{Inovasi pada produk}

Pembaruan inovasi hanya dilakukan oleh salah satu pengusaha di Desa Sumber Kembar yaitu pengusaha kripik ketela yang membuat inovasi produk dengan membuat olahan produk kripik tempe, kripik ketela stik, susu ketela.

Pelaku UMKM lain di Desa Sumber Kembar masih belum membuat inovasi pada produknya karena menurut mereka belum mampu membuat produk dengan varian lain dikarenakan masih belum ada waktu untuk melakukan uji coba kelayakan produk dan masih mengalami keraguan untuk mengalami inovasi karena khawatir tidak akan mampu menembus pasaran, karena pengakuan dari mereka cara pemasaran saja masih dengan cara manual (offline).

UMKM di Desa Sumber Kembar berdiri hanya masih beberapa tahun belakangan, yang terlama pengusaha kripik usus yang sudah berdiri kurang lebih 6 tahunan yang memang belum mengalami inovasi pada produknya. Mempertahankan cita rasa produk memang penting tapi mengabaikan inovasi dalam berwirausaha juga perlu.

\subsubsection{Pengemasan dan pemberian label pada kemasan}

Pengemasan produk dilakukan dengan memberikan label pada wadah produk yang bertujuan sebagai pengenal meskipun masih ada salah satu pelaku UMKM yang belum memberikan label kemasan yaitu pengusaha susu kedelai. Para pelaku UMKM berpendapat kebanyakan masyarakat enggan membeli produk yang tidak memiliki label karena khawatir produk tersebut tidak jelas dan menggunakan bahan bahan aneh yang berakibat menimbulkan respon negatif, jadi pemberian label pada kemasan merupakan hal yang sangat penting. Pembeli akan cenderung melihat sebuah produk dan tertarik apabila memiliki kemasan yang menarik

3 Dampak Penerapan Strategi Pemasaran Dalam Upaya Peningkatan Omset Penjualan UMKM Desa Sumber Kembar, Kecamatan Pacet, Kabupaten Mojokerto

Besar atau kecil suatu usaha akan memberikan pengaruh pada perkembangan perekonomian di Indonesia. Meskipun hanya mempengaruhi sebagian kecil. Akan tetapi UMKM dapat memulihkan suatu kondisi krisis ekonomi yang menerpa suatu wilayah. Keberadaan UMKM juga tak luput dari strategi pemasaran yang mereka terapkan dalam memasarkan produk. Saat ini UMKM sudah merambah di berbagai wilayah di Indonesia dengan keberanekaragaman produk baik di bidang dagang maupun jasa.

Penerapan strategi yang tepat akan menghasilkan dampak yang luar biasa, namun apabila strategi yang diterapkan belum mampu menarik minat konsumen tentu akan memberikan dampak kerugian berupa tenaga dan waktu bahkan uang. Dampaknya ada positif juga ada yang negatif. Setiap pengusaha tentu tidak ingin mengalami dampak berupa kerugian, namun kerugian itu nyata apabila setiap pelaku usaha mengabaikan usaha yang seharusnya ditekuni tersebut. Berikut ini merupakan dampak positif yang didapat dari penerapan strategi pemasaran di Desa Sumber kembar:

3.3.1 Dampak positif penerapan strategi pemasaran dalam upaya peningkatan omset penjualan UMKM desa sumber kembar

Strategi pemasaran yang dilakukan pelaku usaha (UMKM) di Desa Sumber Kembar memiliki dampak positif bagi desa tersebut maupun pelaku usaha itu sendiri yaitu sebagai berikut:

3.3.1.1 Dampak positif bagi desa Sumber Kembar 
Sebagai branding desa ke masyarakat dengan kata lain secara tidak lansung pelaku UMKM yang merupakan warga desa Sumber Kembar yang juga bermukim di Desa Sumber Kembar akan mencantumkan nama desa pada label kemasan. Kemudian masyarakat akan mengenal desa Sumber Kembar dan desa dapat menjadi pusat perhatian masyarakat dan tidak akan terkucilkan.

Semakin banyaknya UMKM yang didirikan di Desa Sumber Kembar maka akan semakin mendesak pengurus desa untuk segera merealisasikan BUMDES. Bukan hanya sekedar wacana. Selain itu saat BUMDES didirikan akan memicu warga yang lain untuk menciptakan produk - produk baru.

\subsubsection{Dampak positif bagi warga}

Dampak positifnya bagi warga yakni membuka lapangan pekerjaan bagi warga di sekitar tempat pemukiman di Desa Sumber Kembar. Warga desa berpendapat bahwa adanya UMKM membuat warga desa sangat terbantu dengan dibukanya lapangan pekerjaan bagi mereka dan dapat menstabilkan kondisi ekonomi keluarga (keuangan menjadi stabil) sehingga meminimalisir warga yang pengangguran. Meskipun upah yang didapatkan masih tergolong rendah akan tetapi mereka sudah merasa cukup terbantu (Laila Maulidah \& Oktafia, 2020)

Dalam kaitannya strategi pemasaran yang dilakukan pelaku UMKM sampai saat ini masih aman meskipun tidak mengikuti perkembangan moderen dengan sistem pemasaran melalui online. Perusahaan masih bisa merekrut karyawan yang berarti permintaan masih stabil bahkan masih memiliki potensi permintaan naik. Meski demikian bukan berarti pelaku usaha dapat merasa aman, jika tidak mengikuti perkembangan jaman maka akan tertinggal.

\subsubsection{Dampak positif bagi pelaku UMKM}

Pelaku UMKM akan merasa diuntungkan karena selain usahanya dapat berjalan dengan baik, juga mendapat dukungan dari lingkungan sekitar. Dukungan dari warga sekitar dapat memberikan dampak positif karena usaha yang didirikan pelaku UMKM akan lebih mudah pengoperasionalannya.

Pada kenyataannya masih sulit dalam melakukan strategi pemasaran berbasis online di Desa Sumber Kembar karena minimnya akses internet disana, namun pelaku usaha menggunakan cara manual (offline) untuk memperkenalkan produk secara lansung ke masyarakat.
Memang membutuhkan kesabaran esktra untuk memperkenalkan produk secara manual (offline) akan tetapi hal tersebut merupakan langkah termudah dalam memasarkan produk terutama di Desa Sumber Kembar. Mengingat aktifitas warga disana adalah pergi ke sawah dan ladang yang mana jarang menggunakan alat elektronik.

3.3.2 Dampak negatif penerapan strategi pemasaran dalam upaya peningkatan omset penjualan UMKM desa sumber kembar

Selain dampak positif, terdapat juga dampak negatif dari perilaku strategi pemasaran yang dilakukan pelaku UMKM di Desa Sumber Kembar. Dampak negatif tersebut diantaranya:

\subsubsection{Produk olahan tidak bertahan lama}

Pengemasan produk tanpa penggunaan bahan pengawet tidak akan bertahan lama. Produk tersebut akan lebih cepat mengalami permbusukan dari pada yang menggunakan bahan pengawet.

Penggunaan bahan pengawet sesuai takaran tidak akan mengubah produk baik dari warna, rasa maupun tampilan. Pada dasarnya pengawet makanan dibuat untuk mngawetkan makanan atau minuman agar ketika di distribusikan ke tempat yang jauh tidak akan cepat busuk dan dapat dikonsumsi dalam jangka panjang.

3.3.2.2 Belum mampu bersaing dengan produk lain berskala nasional

Strategi pemasaran yang dilakukan oleh pelaku UMKM tersebut belum bisa menembus pasar nasional karena pemasaran yang dilakukan masih manual (offline). Pemasaran yang dapat menembus skala nasional dengan cepat yakni dengan memasarkan secara online, namun karena terbatasnya tenaga dan waktu membuat pelaku UMKM enggan meng-online-kan dagangannya.

Setiap usaha pasti akan ada hasilnya. Meskipun usaha berbasis online cukup ribet dalam pemasarannya namun apabila dilakukan dengan tekun tentu akan memperoleh hasil yang memuaskan. Jika pelaku UMKM hanya mengandalkan dagangan mereka secara offline terus menerus tidak menutup kemungkinan mereka akan tergerus oleh zaman dan bahkan omset penjualan mereka dapat turun, meningat usaha mereka adalah pabrik kecil - kecilan yang mana masyarakat masih banyak yang belum mengetahui.

Seperti yang sering kita lihat akhir - akhir ini UMKM di berbagai wilayah semakin merajalela bahkan tak segan - segan rela membayar orang maupun instansi untuk memasarkan produk mereka. Tidak menutup kemungkinan jika terdapat produk di luar kota Mojokerto memiliki produk yang sama namun 
dipasarkan dengan cara yang lebih moderen akan mengalahkan produk dari desa Sumber Kembar itu sendiri yang akhirnya akan berakibat penurunan omset.

\subsubsection{Keterbelakangan pertumbuhan ekonomi}

Metode pemasaran dengan cara manual (offline) bukan langkah yang salah, akan tetapi cara tersebut hanya menarik sedikit minat konsumen dikarenakan tidak semua orang mengetahui produk yang dijual.

\section{Kegiatan pemasaran UMKM} menggunakan langkah online juga maka akan semakin banyak orang yang tau. Tidak hanya orang di Desa Sumber Kembar tapi juga di luar desa tersebut, bahkan di kota - kota lain akan mengetahui produk yang dijual oleh UMKM.

Operasinal UMKM di Desa Sumber Kembar dapat mengalami keterbelakangan karena kurangnya sosialisasi (sharing) dari pelaku usaha kepada UMKM di kota lain mengenai kemajuan alat, pengembangan produk, perencanaan pemasaran dan hal - hal yang dapat memajukan UMKM.

\subsubsection{Kurangnya inovasi produk}

Produk yang telah dibuat sebelumnya oleh pabrik belum mengalami pembaruan atau belum adanya inovasi yang terbaru dan hanya satu pengusaha saja yang malakukan inovasi.

Para pelaku UMKM di Desa Sumber Kembar masih menjajakan produk lama mereka, belum ada produk baru yang diciptakan yang mampu membuat produk mereka menjadi beranekaragam, sehingga membuat kebanyakan orang merasa bosan dengan produk yang hanya itu - itu saja.

Dengan adanya inovasi baru diharapkan mampu menjadikan UMKM desa menjadi lebih aktif dan progresif dalam melakukan kegiatan usahanya sehingga akan tercipta UMKM yang berkemajuan.

\section{KESIMPULAN}

Berdasarkan hasil dari penelitian yang dilakukan oleh peneliti yang terdapat pada bagianbagian sebelumnya, menunjukkan bahwa, Pertama: penerapan strategi pemasaran yang dilakukan dalam upaya peningkatan omset penjualan di Desa Sumber Kembar masih tergolong manual dan lambat dalam pemasarannya, selain itu pelaku UMKM di Desa tersebut tidak semua melakukan inovasi pada produknya. Maka dari itu marketing strategy dengan sistem online juga penting bagi para pelaku UMKM dan inovasi merupakan salah satu langkan dalam marketing strategy. Kedua: dampak penerapan strategi pemasaran dalam upaya peningkatan omset penjualan ada dua yaitu dampak positif dan negatif. Salah satu dampak positif mampu membuka lapangan pekerjaan bagi warga desa itu sendiri, dampak negatifnya strategi pemasaran yang dilakukan oleh pelaku UMKM belum mampu bersaing secara nasional.

\section{UCAPAN TERIMAKASIH}

Penulis mengucapkan terimaksih sebanyak banyaknya kepada kedua orang tua, dosen pembimbing ibu Renny Oktafia, ketua prodi perbankan syariah ibu Fitri Nur Latifah, bapak Hidayatullah selaku rektor universitas muhammadiyah sidoarjo. Tak lupa juga penulis mengucapkan terimakasih pada bapak editor JIEI telah membantu untuk mempublikasikan jurnal ilmiah ini, serta orang - orang baik yang telah membantu saya, kepada pihak - pihak yang tidak bisa saya sebutkan satu persatu, semoga Allah subhanahuwa ta'ala selalu melimpahkan rahmatnnya kepada kita semua.

\section{DAFTAR PUSTAKA}

Agusta, I. (2014). Teknik Pengumpulan dan Analisis Data Kualitatif. Jurnal Studi Komunikasi Dan Media, 02(1998), 1-11.

Arliman S, L. (2017). Perlindungan Hukum Umkm Dari Eksploitasi Ekonomi Dalam Rangka Peningkatan Kesejahteraan Masyarakat. Jurnal Rechts Vinding: Media Pembinaan Hukum Nasional, 6(3), 387. https://doi.org/10.33331/rechtsvinding.v6i3.194

Ayudia, Suryanto, E., \& Waluyo, B. (2016). Analisis Kesalahan Penggunaan Bahasa Indonesia Dalam Laporan Hasil Observasi Pada Siswa Smp. Jurnal Penelitian Bahasa, Sastra Indonesia Dan Pengajarannya, $9(2), \quad 10$. https://www.infodesign.org.br/infodesign/article/v iew/355\%0Ahttp://www.abergo.org.br/revista/ind ex.php/ae/article/view/731\%0Ahttp://www.abergo .org.br/revista/index.php/ae/article/view/269\%0Ah ttp://www.abergo.org.br/revista/index.php/ae/articl e/view/106

Esti Prastika, N., \& Edi Purnomo, D. (2019). Pengaruh Sistem Informasi Akuntansi Terhadap Kinerja Perusahaan Pada Usaha Mikro Kecil Dan Menengah (Umkm) Di Kota Pekalongan. Jurnal Litbang, 1 .

Firmansyah, A. (2019). Pemasaran Produk dan Merek (Planning and Strategy). Penerbit Qiara Media.

Hendrawan, A., Kuswantoro, F., \& Sucahyawati, H. (2019). Dimensi Kreativitas dan Pengembangan Usaha Mikro Kecil dan Menengah ( UMKM ). 2(1990), 25-36. 
Jatmika, S., Aprilianto, T., \& Poernomo Tri Prasetyo, B. (2017). E-Marketing Dengan Media Jejaring Sosial Untuk Peningkatan Omset Penjualan. September, 646-654.

Kementerian Perencanaan Pembangunan Nasional. (2018). Ekonomi Syariah Indonesia 2019-2024.

Kurnia, H. (2019). Realisasi Dana Amal Sosial (Amsos) Majelis Ta'lim Pt.Bormindo Nusantara Dalam Pemberdayaan Anak Yatim Di Kelurahan Batang Obo Kecamatan Bathin Salopan Duri (Issue 3823). Universitas Islam Negeri Sultan Syarif Kasim Riau.

Laila Maulidah, F., \& Oktafia, R. (2020). Strategi Pengembangan Usaha Kecil Dan Mikro Serta Dampak Kesejahteraan Masyarakat Desa Kweden Kecamatan Tarik Kabupaten Sidoarjo ( Menurut Pandangan Maqashid Syariah ). Jurnal Ilmiah Ekonomi Islam, 6(03), 571-581.

Nilamsari, N. (2014). Memahami Studi Dokumen Dalam Penelitian Kualitatif. Wacana, 13(2), 177181.

Oktafia, R. (2017). Percepatan Pertumbuhan Usaha Mikro , Kecil Dan Menengah ( UMKM ) Melalui Perkuatan Lembaga Keuangan Mikro Syariah ( LKMS ) Di Jawa Timur. 110, 85-92.

Priangani, A. (2013). Memperkuat Manajemen Pemasaran Dalam Konteks Persaingan Global. Jurnal Kebangsaan, 2(4), 1-9.
Rukajat, A. (2018). Pendekatan Penelitian Kualitatif (C. Morris Sartono (ed.); 1st ed.). Deepublish.

Sarfiah, S. N., Atmaja, H. E., \& Verawati, D. M. (2019). Umkm Sebagai Pilar Membangun Ekonomi Bangsa. Jurnal REP ( Riset Ekonomi Pembangunan ), 4(1), 137-146.

Sartika, E. (2014). Analisis Isi Kualitatif Pesan Moral dalam Film Berjudul "Kita Versus Korupsi." EJournal Ilmu Komunikasi, 2(2), 63-77.

Sembiring, M., \& Siregar, E. (2020). Pelatihan Strategi Pemasaran, Bisnis Dan Keuangan Produk Rumahan Masyarakat Desa Durian Kec. Pantai Labu. Jurnal Abdidas, 1(4), 277-283.

Setiawati, I. (2017). Pengaruh Strategi Pemasaran Online Terhadap Peningkatan Laba Umkm. Strategi Komunikasi Pemasaran, 20, 1-5. file://C:/Users/BAYU/Downloads/Documents/26 3-760-1-PB.pdf

Sugiarto, E. (2015). Menyusun Proposal Penelitian Kualitatif (Skripsi dan Tesis) (Pertama). Suaka Media.

Wibowo, D. H., Arifin, Z., \& Sunarti. (2015). Analisis Strategi Pemasaran Untuk Meningkatkan Daya Saing UMKM. Jurnal Administrasi Bisnis, 29(1), 59-66.

Yunus, E. (2016). Manajemen Strategis (A. Ari Christian (ed.); I). Penerbit Andi. 